\title{
DE MIM JÁ NEM SE LEMBRA E O LEGADO ROMANESCO EM PERSPECTIVA CONTEMPORÂNEA
}

DE MIM JÁ NEM SE LEMBRA AND THE LEGACY OF NOVEL IN CONTEMPORARY PERSPECTIVE

RUFFATO, LUIZ. DE MIM JÁ NEM SE LEMBRA. SÃO PAULO: COMPANHIA DAS LETRAS, 2016.

Lucas Zamberlan*

O teórico Ian Watt, em $A$ ascensão do romance, traça um perfil político, econômico e social da Inglaterra do século XVIII para explicar as relações estéticas entre a lógica capitalista e o surgimento do romance. O tempo passou, a narrativa evoluiu, e o capitalismo acabou passando por uma série de transformações, adaptando-se às novas demandas e diferentes processos. Da mesma forma, o gênero se multifacetou, rompendo barreiras e se reinventando por veredas que acompanham os rumos de uma realidade cada vez mais fragmentada e incerta.

O novo livro do escritor Luiz Ruffato, denominado De mim já nem se lembra, surge, pois, nesse contexto contemporâneo, como um produto cultural que oferece algum sentido
* lucaszamberlan@yahoo.com.br

Professor Substituto do Departamento de Letras Vernáculas do Curso de Letras da Universidade Federal de Santa Maria (UFSM) e Doutorando do Programa de Pós-Graduação em Letras da mesma instituição.

ao paradoxo da arte atual que implica tradição e novidade, conservação e revolução. Ao mesmo tempo que a obra pode ser lida de forma prosaica, quase como uma não-literatura, ela fornece um conjunto de elementos, estrategicamente tecidos, que não só aprofundam a leitura, mas também remetem a momentos cruciais da história do romance, desde a sua invenção até aos dias de hoje.

O livro apresenta, logo no seu início, uma explicação necessária. Nela, Ruffato evidencia a coexistência de tempos narrativos que aproximam a experiência de morte da mãe do narrador (também chamado de Luiz Ruffato), em 2001, até a sua decisão, já em 2008, de abrir o conjunto de cartas que o seu irmão, José Célio, havia mandado para sua mãe durante 
1. RUFFATO. De mim já nem se lembra, p. 22. o período de sete anos (1971-1978) que viveu em Diadema, trabalhando como operário até tornar-se vítima fatal de um acidente automobilístico:

Em fins de 2003, empacotava objetos para mais uma mudança de endereço - a vigésima sexta em minha vida -, quando ao retirar livros de uma prateleira na estante, me deparei com o maço de cartas. Imediatamente, sentei-me no chão empoeirado do apartamento vazio e desatei o barbante. Cuidadosamente enfileiradas por data, cinquenta cartas sobrescritadas por meu irmão à minha mãe. Perturbado, percorri, uma a uma, as páginas compostas em letra miúda e desenhada, relatando ninharias, reclamando novidades. Aqui reúno este passado modo de reparar meus mortos, que já pesam no lado esquerdo: meu irmão, minha mãe, meu pai, aqueles aos quais me reunirei um dia. A eles, este livro. ${ }^{1}$

Dessa forma, o romance se arquiteta em três partes intrinsecamente ligadas que põem em relevo, fingidamente, a figura do narrador mais como um organizador de escrituras alheias do que propriamente como ficcionista. No fim da experiência necessária, primeira das três seções, o narrador afirma que arranjou as cartas (segunda parte) da melhor maneira, abrindo espaço para que uma narrativa diferente se apresente, cheia de oralidades, expressões coloquiais e demarcações culturais do falar mineiro, como na passagem:
Lá em Leopoldina, esperando o ônibus que vinha de Alegre, veja só o nome da cidade, e eu numa tristeza que dói, eu fiquei besta num canto, com uma vontade danada de pegar minha mala e voltar para casa, abraçar a senhora e o pai, a Lúcia, o Luisinho, e falar, não, não quero voltar não, mas eu sei que não posso fazer isso, que a gente não escolhe os caminhos e que meu dever é tentar ganhar a vida em São Paulo. Mas não é fácil. ${ }^{2}$

E, por fim, ainda, há um apêndice escrito com extremo lirismo no qual o narrador escreve ao irmão, estabelecendo um contato belo e literariamente possível se criarmos a compreensão de que o receptor daquela última carta é o próprio leitor e que estamos diante de uma obra de arte.

Ora, a utilização de cartas no corpo do romance como recurso preeminente de emprestar maior veracidade ao enredo não é nova e remonta a um dos fundadores do gênero na Inglaterra: Samuel Richardson. Após analisar das contribuições de Defoe à prosa do século XVIII, Watt encontra em Richardson um escritor que lança mão da literatura epistolar para acrescentar dois ingredientes que, desde então, são a base do repertório romanesco: a subjetividade e a ênfase na vida doméstica. Esses elementos, segundo o autor, misturados com outros tantos, como o aconchego do lar como refúgio dos problemas que a urbe apresenta, explicita a experiência privada e possibilita a promoção de um mergulho
2. RUFFATO. De mim já nem se lembra, p. 39.

EM TESE BELO HORIZONTE $\quad$ v. $23 \quad$ N. $1 \quad$ JAN.ABR. 2017 ZAMBERLAN. De mim já nem se lembra e o legado romanesco em [...] $\quad$ P. 304-307


3. RUFFATO. De mim já nem se lembra, p. 114. vertiginoso na composição íntima da personagem, destacando sua individualidade, uma das premissas do herói romanesco, bem como do próprio liberalismo.

Assim, a leitura de De mim já nem se lembra ramifica-se, rizomaticamente, para utilizar os termos de Deleuze Guattari, em múltiplas possibilidades de leitura, principalmente no que tange à literatura comparada, associando arte literária com reflexões sobre a sociologia e a história, por exemplo. Essas possibilidades açulam a atenção do leitor para aspectos que, apesar da abordagem natural intermediada pela simplicidade da personagem José Célio, concorrem no sentido de expor um Brasil amordaçado pela Ditadura Militar, mas que já esboçava um descontentamento perante essa condição, como em:

Que ele está em Diadema para vigiar a gente e entregar para o governo, porque a senhora sabe que a gente vive debaixo de uma ditadura que prende e mata trabalhadores, que a única coisa que querem é mudar a situação injusta do país, mas senhora nem fale isso aí em Cataguases não, senão eles ainda prendem a senhora e dizem que a senhora é comunista.

Nos sete anos em que o irmão de Luizinho - apelido do narrador - esteve em Diadema, o que mais chama a atenção é o amadurecimento de ordem pessoal e profissional da personagem que mitiga o desassossego de estar longe da terra natal, Cataguases, e dos familiares. Qual um Ulisses às avessas desamparado pelos deuses, que no lugar de sua astúcia tem apenas um diploma do Senai, Célio erra de pensão em pensão, colecionando amizades fugazes, mas sinceras, de trabalhadores que se irmanam na solidão. Da obediência servil dos primeiros anos, nasce, em uma evolução muito coerente elaborada pelo autor, uma consciência crítica que é apenas ceifada pelo acidente inesperado, como inesperado e inexplicável é o destino das personagens dos romances contemporâneos.

Ademais, são os detalhes que constroem a natureza complexa e a multiplicidade interpretativa mencionada, em acordo com que Linda Hutcheon chama, na literatura, de "Duplo código". Esse recurso, de caráter irônico e implicitamente intertextual, consiste em deixar pistas ao leitor, no decorrer da história, que as relacionem com outros produtos culturais, mas que não prejudicam a leitura do receptor que não percebe o que Umberto Eco denomina de "piscada de olho" que o autor dá a esse leitor. ${ }^{4}$

Desde as cartas que nos ligam ao berço do romance - seja Richardson, Laclos ou Alencar, no Brasil - ao autor-editor do livro; do personagem interiorano que enfrenta as dificuldades na cidade grande - que incorpora, com acuidade, as imposições do capitalismo - ao relacionamento baseado em admiração entre irmão mais novo e irmão mais velho, tudo é, paradoxalmente, invenção e repetição na mesma medida.
4. ECO. Confissões de um jovem romancista, p. 29-32.

EM TESE BELO HORIZONTE $\quad$ v. $23 \quad$ N. $1 \quad$ JAN.ABR. $2017 \quad$ ZAMBERLAN. De mim já nem se lembra e o legado romanesco em [...] $\quad$ P. 304-307


5. ROSA. Manuelzão e Miguilim: (Corpo de Baile), p. 119.
A "piscada de olho" mais marcante, realizada por Ruffato, aborda justamente este último tema. Na última carta escrita por José Célio, ele informa que fará sua primeira grande viagem com um Fusca 1972, comprado recentemente, acompanhado de um amigo de Mutum. Em nota de rodapé, o narrador-organizador-personagem reflete sobre a existência desse amigo, acreditando que o irmão o havia inventado para tranquilizar a mãe. No entanto, ao mencionar a cidade mineira Mutum, Ruffato acena para o seu leitor, fazendo com que resgatemos na memória a obra Manuelzão e Miguilim (2001), de Guimarães Rosa, na qual a morte de Dito, irmão mais velho do protagonista Miguilim, vem acompanhada do seu ensinamento derradeiro: "Miguilim, Miguilim, vou ensinar o que agorinha eu sei, demais: é que a gente pode ficar sempre alegre, alegre, mesmo com toda coisa ruim que acontece acontecendo. A gente deve de poder ficar então mais alegre, mais alegre, por dentro!..."

Essa lição, Miguilim aprendeu e parece repassar ao também mineiro e caçula Luizim (como é chamado, às vezes, por Célio).

Por contar com traços como esses, De mim já nem se lembra não só guarda um pouco das grandes obras da literatura de outros tempos, mas demonstra, também, como compartilhar, à sua maneira, a sabedoria comum a todas elas.

\section{REFERÊNCIAS}

DELEUZE, G.; GUATTARI, F. Rizoma. In: Mil platôs. Aurélio Guerra Neto e Célia Pinto Costa. São Paulo: 34, 1995. Vol.1.

ECO, Umberto. Confissões de um jovem romancista. Marcelo Pen. São Paulo: Cosac Naify, 2013

HUCHEON, Linda. Poética do pós-modernismo: história, teoria, ficção. Ricardo Cruz. Rio de Janeiro: Imago, 1991.

ROSA, João Guimarães. Manuelzão e Miguilim: (Corpo de Baile). Rio de Janeiro: Ed. Nova Fronteira, 2001.

RUFFATO, Luiz. De mim já nem se lembra. São Paulo:

Companhia das Letras, 2016.

WATT, lan. A ascensão do romance. Hildegard Feist. São Paulo: Companhia das Letras, 1990 